\title{
Magnitude and Associated Factors of Protein Energy Malnutrition among Children Aged 6-59 Months in Wondogenet District, Sidama Zone, Southern Ethiopia
}

\author{
Kaleb Mayisso Rodamo ${ }^{1, *}$, Yonas Alemayehu Fiche ${ }^{1}$, Fisseha Bonja Geleto ${ }^{1}$, Rekiku Fikre Abebe ${ }^{1}$, \\ Desalegn Dabaro Dangiso ${ }^{2}$
}

${ }^{1}$ Faculty of Health Sciences, College of Medicine and Health Sciences, Hawassa University, Hawassa, Ethiopia

${ }^{2}$ Department of Social and Population Health, Yirgalem Hospital Medical College, Yirgalem, Ethiopia

Email address:

kalebmayisso@gmail.com(K. M. Rodamo),yoaleb2j@gmail.com(Y. A. Fiche), fisseha.bonja@gmail.com(F. B. Geleto), frekiku@yahoo.com(R.F. Abebe), desalegndabaro2016@gmail.com(D. D. Dangiso)

${ }^{*}$ Corresponding author

\section{To cite this article:}

Kaleb Mayisso Rodamo, Yonas Alemayehu Fiche, Fisseha Bonja Geleto, Rekiku Fikre Abebe, Desalegn Dabaro Dangiso. Magnitude and Associated Factors of Protein Energy Malnutrition among Children Aged 6-59 Months in Wondogenet District, Sidama Zone, Southern Ethiopia. Journal of Gynecology and Obstetrics. Vol. 6, No. 3, 2018, pp. 47-55. doi: 10.11648/j.jgo.20180603.13

Received: February 9, 2018; Accepted: March 13, 2018; Published: June 14, 2018

\begin{abstract}
Background: Failure to provide sufficient nutrients during rapid rates of growth results in malnutrition, which is complex in its etiology and increasing in its manifestations. Ethiopia is one of the developing countries where malnutrition and communicable diseases represent the major health problems, and children are the more vulnerable group than others. Objectives: To assess magnitude of protein energy malnutrition and associated factors among children aged 6-59 months in Wondogenet district, southern Ethiopia. Methods: A community based cross-sectional study was employed on 422 motherchild pairs of 6-59 months old children in April 2017 using both quantitative and qualitative methods. A pretested semistructured questionnaire and anthropometric measurement were used to collect data. Logistic regression was fitted to identify associated factors, and Focused Group Discussion was used to substantiate the quantitative finding. Result: The analysis of this study revealed that, $45.5 \%, 38.7 \%$ and $15.7 \%$ of children were stunted, underweight and severely wasted respectively. The major predictors of stunting were weight at birth and food distributions in the households. Age of the children was independently associated with wasting and underweight. Conclusion: The prevalence of malnutrition among children aged 659 months in the study area was very high. A child less than 2 years of age, a weight $<2.5 \mathrm{~kg}$ at birth and deprived special attention during feeding children in the households were associated with increased odds of being malnourished. Thus, it is recommended that the parents and care givers should strive to improve the awareness on timely introduction of supplementary food with optimum nutritional value for children less than 2 years of age, and to pay special attention for children on meal time. Birth attendants should pay due attention on proper identification for birth weight and early diagnosis and on time management of neonatal illnesses related with low birth weight.
\end{abstract}

Keywords: Protein Energy Malnutrition, Stunting, Underweight, Wasting, Children Aged 5-59 Months

\section{Background}

Malnutrition remains among the most devastating problems worldwide, particularly facing the worlds under privileged and poor. It covers a broad spectrum of illness, including under nutrition, specific nutrient deficiencies and over nutrition. The persistent crisis of malnutrition has profound and frightening effects for children, society and future of human kind. It is not a simple matter of whether a child can satisfy his or her appetite but a child who eats enough to satisfy immediate hunger can still be malnourished. In addition, malnutrition is not just a silent emergency; it is largely an invisible one as well. Three quarters of children who died worldwide of causes related to malnutrition are what nutritionists describe as mildly to 
moderately malnourished $[1,2]$. Around half of all deaths in under-five children are related to under nutrition [3]. Globally, about 800 million people are affected with malnutrition, majority of them live in the developing countries [4]. According to WHO report, about 178 million children are stunted, while 115 million children are under weight. The report adds that the stunting rate is higher in African and Asia than anywhere in the world [5].

More than half of all deaths in children are stunting and wasting as the underlying cause; they are too thin or too short for their age because they have not had sufficient type II nutrients (the growth nutrients that are required to build new tissue) to grow properly and many have lost weight. These children would have recovered from other illnesses if they had not been malnourished, but because they are malnourished, they die. Thus, most deaths in childhood have some form of malnutrition as the underlying cause. Stunting is due to chronic malnutrition while wasting and edema are due to acute malnutrition [6].

Deficiency of a single nutrient is an example of under nutrition or malnutrition, but deficiency of a single nutrient usually is accompanied by a deficiency of several other nutrients. Protein-energy malnutrition (PEM) is manifested primarily by inadequate dietary intakes of protein and energy, either because the dietary intakes of these 2 nutrients are less than required for normal growth or because the needs for growth are greater than can be supplied by what otherwise would be adequate intakes. PEM is almost always accompanied by deficiencies of other nutrients [7]. Underfive children are the most susceptible age group for malnutrition. Malnutrition at the early stages of life can increase risk infections, morbidity, and mortality together with decreased mental and cognitive development. The effect of child malnutrition is long lasting and goes beyond childhood. For instance, malnutrition during early age decreases the educational achievement and labor productivity and raises the risk of chronic illnesses in later age [8-10]. Malnutrition is the major cause of illness and death among under-five children in Ethiopia. The rate of malnutrition among under-five children in the country is among the highest in the world and Sub-Saharan Africa. Moreover, malnutrition is the underlying cause for three-fifth of child death in the country [11-13]. According to the 2014 Ethiopian Mini Demographic and Health Survey (EMDHS) report, $42 \%, 26.7 \%$, and $9 \%$ of under-five children were stunted, underweight, and wasted, respectively. The problem is even worse in rural areas. For instance, the prevalence of underweight and stunting among rural children was $27 \%$ and $42 \%$ compared with only $13 \%$ and $24 \%$ among urban children, respectively [14]. The planning of an appropriate intervention requires the knowledge of the extent and the underlying causes of the problem. Thus, Protein Energy Malnutrition of under-five aged children is a public threat in Ethiopia, and there is no adequate scientific evidence in Sidama zone, south Ethiopia. Hence the aim of this study was to assess the magnitude and associated factors of Protein energy malnutrition among children aged 6-59 months at
Wondogenet district, Sidama zone, southern Ethiopia.

\section{Methods}

The study was conducted in Wondogenet district, southern Ethiopia in April 2017. A community based cross-sectional study was employed using both quantitative and qualitative data collection methods. The study included mother-child pairs of 6-59 months old children who were permanent residents at least for one year in the study area.

The Sample size was determined by single population proportion formula, $\mathrm{N}=\mathrm{Z} \quad(\alpha / 2)^{2} \times \mathrm{p} \quad(1-\mathrm{p}) / \mathrm{d}^{2}$ with assumption of $48.5 \%$ prevalence of malnutrition among rural children from previous study in Ethiopia [15]. The estimated sample size was desired to be precise at a confidence level of $95 \%$, a margin of error of $5 \%$ and considering $10 \%$ of non-response rate that resulted in 422 . The district was selected by purposive sampling technique while 4 of $13(30.8 \%)$ kebeles (smallest unit of administration) were selected by simple random sampling technique. The total sample size was distributed among selected kebeles using simple random sampling technique.

The dependent variable of measure was: - Protein energy malnutrition indicated by wasting, stunting and underweight status in children 6-59 months of age.

While the independent variables of the study were:-

1. Socio-demographic and economic variables:- Age of child and mothers, child sex, family size, income status of the family, maternal/paternal education and occupation, marital status of the mother and number of livestock owned.

2. Maternal caring practices during pregnancy:- ANC visits, place of delivery, assistant at delivery, nutrition awareness, number of children ever born, prepregnancy weight, health status during pregnancy, use of extra food during pregnancy and autonomy in decision-making.

3. Child characteristics: - Weight at birth, height and weight at childhood, birth order and history of neonatal and childhood illness of children aged 6-59 months.

4. Child caring practices: - Immunization status, time of colostrum feeding initiation, exclusive breast feeding and complementary food initiation.

5. Maternal knowledge and practice on: - Feeding children and malnutrition risks (diarrhea, intestinal parasites...); food distribution experience in the family.

6. Environmental health condition and personal hygiene practice:-Housing conditions, solid and liquid waste management, water supply, sanitation and hygiene facilities were assessed as independent variables of protein energy malnutrition of children aged 6-59 months.

A semi- structured questionnaire adapted from Ethiopian demographic and health survey [16] was used for data collection. Interviewers and supervisors were trained in data collection and measurement techniques for two days. Four diploma graduated health professionals speaking local language (Sidaamu afoo) and working outside the study 
kebeles collected the data by conducting face-to-face interview with mother in their home with the support of one supervisor holding Bachelor of Science in nursing. In addition, focus group discussion had been conducted with three focus groups, each consisting of six to eight participants selected from currently delivered women and their husbands. Furthermore, community elders were involved in focused group discussion (FGD) in order to elicit their perception towards nutritional status of children aged 6-59 months. The questionnaire was pretested on $5 \%$ of the respondents in Yuwo village, neighboring the study kebeles. Data was checked for completeness and cleanness, and analyzed by SPSS version 20.0. The result was presented using tables and figures. Qualitative data from FGD was analyzed by thematic areas and triangulated with quantitative findings.

Ethical clearance was obtained from ethical Review committee of College of medicine and Health Sciences, Hawassa University. The regional health bureau and other respective offices were informed by letters while verbal consent was obtained from respondents during data collection.

\section{Result}

\subsection{Socio- demographic and Economic Characteristics of Study Participants}

A total of 422 heads of households were interviewed with a response rate of $90.5 \%$. Among the respondents, majority $(94.5 \%)$ were mothers with the age range between $20-49$ years old. The higher proportions $(95.2 \%)$ of the mothers were married within the mean age $21.61 \pm 2.269$ years at first marriage. About half $(58.3 \%)$ of the respondents had attended 1-6 grade and $43.8 \%$ of them were married to husbands completed at least secondary school. Majorities $(89.8 \%)$ of the respondents were farmers, $11 \%$ were governmental employee and $31 \%$ were engaged in trade with average annual income of 10,000 and 25,000 ETB respectively. In addition, $62.9 \%$ of the respondents were protestant religion followers, and about the quarter had more than four family members per households (Table 1).

Table 1. Socio - demographic and Economic and Characteristics of Study Participants in Wondogenet district Sidama zone, Southern Ethiopia April 2017.

\begin{tabular}{|c|c|c|c|}
\hline Variables & & Frequency & Percent \\
\hline \multirow{3}{*}{ Maternal age $(n=382)$} & $\leq 19$ & 12 & 3.1 \\
\hline & $20-49$ & 361 & 94.5 \\
\hline & $50+$ & 9 & 2.4 \\
\hline \multirow{3}{*}{ Maternal educational status $(\mathrm{n}=382)$} & Illiterate & 72 & 18.8 \\
\hline & Primary school & 223 & 58.4 \\
\hline & Secondary school above & 87 & 22.8 \\
\hline \multirow{2}{*}{ Maternal occupation $(n=382)$} & House wife & 220 & 57.6 \\
\hline & Government employee & 42 & 11.0 \\
\hline \multirow{3}{*}{ Average annual family income $(\mathrm{n}=382)$} & $<10,000$ & 100 & 26.2 \\
\hline & $10,000-50,000$ & 214 & 56.0 \\
\hline & $>50,000$ & 68 & 17.8 \\
\hline
\end{tabular}

\subsection{Maternal Caring Practice During Pregnancy in Wondogenet District, Sidama Zone Southern Ethiopia, April 2017}

Two hundred twenty two (58.1\%) of the mothers had given birth at health facilities by skilled birth attendants; 217 (97.7\%) of them experienced spontaneous vaginal mode of delivery and majority, $64.8 \%$ of their neonates' weight lied at normal range $(2.5 \mathrm{~kg}-3.5 \mathrm{~kg})$ at birth with only a few proportion, $58(15.2 \%)$ of them were recorded as underweighted. Concerning bad obstetric conditions, only seventy one and twenty six of the mothers had experienced at least one of the conditions and referred to higher medical institutions respectively. Among complications related to child birth, above half of the cases being excessive vaginal bleeding followed by $33.3 \%$ of prolonged labor (Figure 1 ).

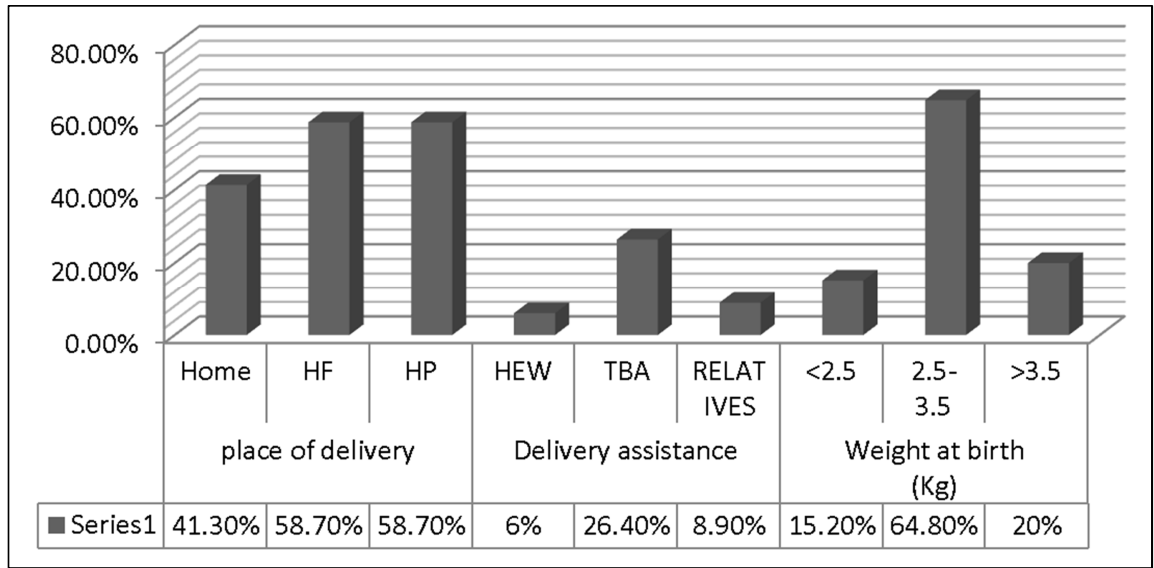

Figure 1. Maternal Caring Practice during Pregnancy in Wondogenet District, Sidama Zone Southern Ethiopia April 2017. 


\subsection{Reasons Why Pregnant Mothers Preferred Giving Birth at Home to Health Facility in Wondogenet District, Sidama Zone Southern Ethiopia, April 20017}

One hundred and sixty $(41.8 \%)$ of the mothers had given birth at home in the current study. Different reasons were mentioned for preferring home delivery than health facility. Forty percent of the participants expressed the occurrences of inconvenient incidences during labor and delivery in the facilities. Thus, 35\% of them were not satisfied with the skilled birth attendant services, and consequently resulted in poor health seeking behavior. In addition, $45.6 \%$ participants have traditional birth attendants at their neighborhoods, thus could be pretended to attend traditional than skilled birth attendances.

The FGD participants shared these perceptions, associating the lower utilization of the service with the lower decision making power of women to choose where they give birth. In addition, shortage of equipment and supplies in the health facilities and, unwelcoming behaviors of providers may affect their preferences. A forty five years old woman participant stated as "...in rural areas health facilities are not attractive for mother because of unclean equipment, bad odor, lack of water and electric power, inconvenient coach of delivery and the professionals are not sensible to attend mothers and not keeping privacy in difficult labor" (Table 2).

Table 2. Reasons why pregnant mothers preferred giving birth at home to health facility in Wondogenet district, Sidama zone southern Ethiopia, April 20017.

\begin{tabular}{lll}
\hline Variables & Frequency & percent \\
\hline Presence of traditional birth attendants $(\mathrm{n}=160)$ & 43.6 \\
Occurrence of a problem during labour and delivery $(\mathrm{n}=160)$ & 64 \\
Inaccessibility of health facility $(\mathrm{n}=160)$ & 0 \\
Dissatisfaction in services delivered $(\mathrm{n}=160)$ & 56.0 \\
In affordability of services $(\mathrm{n}=160)$ & 0.0 \\
Partner was not cooperative $(\mathrm{n}=160)$ & 35.0 & 0.0 \\
\hline
\end{tabular}

\subsection{Children Characteristics and Child Caring Practices in Children Aged 6-59 Months in Wondogenet District Sidama Zone, Southern Ethiopia April 2017}

Three hundred and fifty six (93.2\%) of the mothers had initiated colostrum feeding after an hour of birthing and high proportion $260(68.1 \%)$ of them had practiced exclusive breast-feeding until the completion of six months. Contrary to that, only $121(31.7 \%)$ of the mothers had experienced breast-feeding for more than 2 years and $249(65.2 \%)$ of them started complementary feeding at full of six months. High proportion, $43.2 \%$ of the mothers had used cow's milk as complementary food most of the time. As frequency of feeding and dish utilization experience concerned, only $34.6 \%$ and $78.0 \%$ of the children used to consume more than four meals per day and had been managed in separate dish respectively. With regard to food distribution experience for children, a high proportion, $69.9 \%$ of the parents used to give priority for children below five years.

Lower experience of breast feeding for more than two years leads to lower decision making power of women to use modern family planning. One of the FGD participants stated this concern as "...in rural areas women are not sole decision makers on modern family planning methods utilization and deciding on the number of children they would have and when they should conceive the next baby, however the partner's decision is always placed on upper stairs."

Regarding the neonatal weight, higher proportion 248 (64.9\%) of neonates' weight at birth lied at a range of 2.5-3.5 kilograms. Majorities, $75.9 \%$ and $81.15 \%$ of the children were identified in normal range of weight for height and weight for age respectively. As anthropometric condition concerned, $45.5 \%$ of the children were presented with stunting, $38.7 \%$ underweight and $15.7 \%$ severe wasting. In the case of immunization status of the children, majority 288 $(75.4 \%)$ of them were declared as fully vaccinated, and the immunization card of $265(69.4 \%)$ were verified at their home. According to the report, only $12.3 \%$ of the children had received some part of scheduled vaccination, $22(5.8 \%)$ missed measles and the remaining (14.1\%) were not ever vaccinated. Regarding the health status of the children, 168 $(44.1 \%)$ had at least one episode of illness in their life time and $96(57.1 \%)$ of them had diarrheal disease; $74.7 \%$ were presented with wasting on physical examination (Table 3 ).

Table 3. Child Caring Practices and Characteristics of Children Aged 6-59 Months in Wondogenet District, Sidama Zone Southern Ethiopia April 2017.

\begin{tabular}{|c|c|c|c|}
\hline Variable & Options & Frequency & Percent \\
\hline \multirow{3}{*}{ Time of BF Initiated after birth/ Fed colostrum $(n=382)$} & After 1 hour & 356 & 93.2 \\
\hline & Within an hours & 26 & 6.8 \\
\hline & After 6 hours & 4 & 1.0 \\
\hline \multirow{2}{*}{ Mothers experienced Exclusive BF ( $\mathrm{n}=382$ ) } & Yes & 260 & 68.1 \\
\hline & No & 122 & 31.9 \\
\hline \multirow[b]{2}{*}{ Complementary Feeding Practice $(n=382)$} & Before 6 months & 61 & 16.0 \\
\hline & At 6 months & 249 & 65.2 \\
\hline \multirow{3}{*}{ Complementary Feeding mostly received $(n=382)$} & Cow's milk & 165 & 43.2 \\
\hline & Powder milk & 40 & 10.5 \\
\hline & Gruel & 84 & 22.0 \\
\hline
\end{tabular}




\begin{tabular}{|c|c|c|c|}
\hline Variable & Options & Frequency & Percent \\
\hline \multirow{4}{*}{ Duration of $\mathrm{BF}(\mathrm{n}=382)$} & Adults' food & 93 & 24.3 \\
\hline & $<1$ year & 66 & 17.3 \\
\hline & 1year-2year & 195 & 51.0 \\
\hline & $>2$ years & 121 & 31.7 \\
\hline \multirow{4}{*}{ Frequency of feeding per day $(\mathrm{n}=382)$} & Once & 26 & 6.8 \\
\hline & Twice & 28 & 7.3 \\
\hline & Three times & 196 & 51.3 \\
\hline & Four or more times & 132 & 34.6 \\
\hline \multirow{3}{*}{ Feeding on separate dish $(n=382)$} & Yes & 298 & 78.0 \\
\hline & No & 84 & 22.0 \\
\hline & Stunted & 174 & 45.5 \\
\hline \multirow[t]{2}{*}{ Anthropometric condition of children $(\mathrm{n}=382)$} & Underweighted & 148 & 38.7 \\
\hline & Severely wasted & 60 & 15.7 \\
\hline \multirow{4}{*}{ Immunization Status of Children $(n=382)$} & Fully immunized & 288 & 75.4 \\
\hline & Not ever immunized & 54 & 14.1 \\
\hline & Missed BCG & 18 & 4.7 \\
\hline & Missed Measles & 22 & 5.8 \\
\hline
\end{tabular}

\subsection{Mothers'/Care Givers' Personal Hygiene Practice in Wondogenet District, Sidama Zone Southern Ethiopia, April 2017}

High proportion 279 (73\%) of the mothers/care givers had not owned appropriate materials for keeping menstruation hygiene. This is because of they are not such aware of the scientific facts and hygienic health practices which sometimes may result into adverse health outcomes. About $52.6 \%$ of the mothers/care givers had practiced hand washing before cooking food. In addition, $47 \%$ had received the shower less frequently (Figure 2).

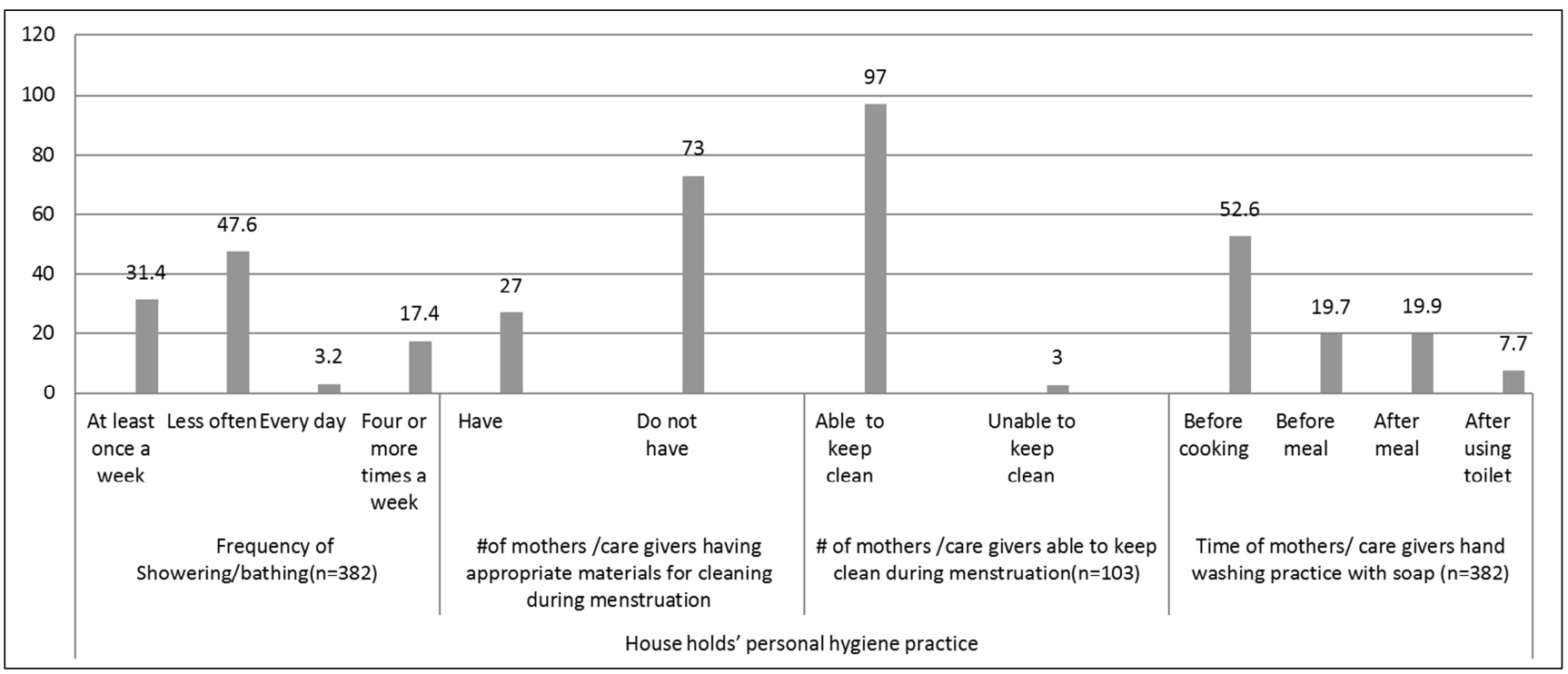

Figure 2. Mothers/Care Givers Personal Hygiene Practice in Wondogenet District, Sidama Zone Southern Ethiopia, April 2017.

\subsection{Status of Water for Drinking and Domestic Use and Environmental Health Condition at Household Level in Wondogenet District, Sidama Zone Southern Ethiopia, April 2017}

Higher proportion, $78.5 \%$ of the households had sufficient water for drinking and domestic use but only $52 \%$ of them had been used tap water for both drinking and domestic activities. In the study, high proportion 234 (61.2\%) of the households did not have solid waste management system and having not taken any action to collect and segregate solid wastes produced in domestic action. Moreover, only $6 \%$ of the households used to collect solid waste products in weekly base and only $153(40 \%)$ of them had sanitation facility for safe disposal of liquid waste and human excreta. High proportion $(74 \%)$ of the households were used to defecate in open field and around bushes and $67 \%$ of the households did not have sanitary facility and sewerage system for safe disposal of waste water and all domestic effluents. According to the study, majority $314(82.2 \%)$ of the households and 68 percent of them were used to live in houses corrugated with iron sheet and constructed with concrete floor respectively (Table 4). 
Table 4. Environmental Health condition and status of water for drinking and domestic use at household level in Wondogenet district, Sidama zone southern Ethiopia April 2017.

\begin{tabular}{|c|c|c|c|c|}
\hline Variable & & & Frequency & Percent \\
\hline \multirow{5}{*}{$\begin{array}{l}\text { Source and sufficiency of drinking domestic } \\
\text { water }(\mathrm{n}=382)\end{array}$} & \multirow{3}{*}{ Source of drinking domestic water } & Tape water & 202 & 52.9 \\
\hline & & Well water & 112 & 29.3 \\
\hline & & Other sources & 68 & 17.8 \\
\hline & \multirow{3}{*}{$\begin{array}{l}\text { Sufficiency of drinking domestic } \\
\text { water }\end{array}$} & Yes & 300 & 78.5 \\
\hline & & No & 82 & 21.5 \\
\hline \multirow{4}{*}{ Solid Waste Management $(\mathrm{n}=382)$} & & Once per week & 23 & 6.0 \\
\hline & \multirow{3}{*}{ Frequency of solid waste disposal } & Every two weeks & 80 & 20.9 \\
\hline & & Every months & 45 & 11.8 \\
\hline & & No action taken at all & 236 & 61.8 \\
\hline \multirow{8}{*}{$\begin{array}{l}\text { Households' Sanitation facilities, liquid } \\
\text { waste and human excreta disposal system } \\
(\mathrm{n}=382)\end{array}$} & \multirow{2}{*}{ Having solid waste disposal system } & Yes & 148 & 38.7 \\
\hline & & No & 234 & 61.3 \\
\hline & \multirow{2}{*}{ Availability of Sanitation facilities, } & Yes & 152 & 39.8 \\
\hline & & No & 230 & 60.2 \\
\hline & \multirow{2}{*}{ Safe disposal of waste water } & Yes & 126 & 33.0 \\
\hline & & No & 256 & 67.0 \\
\hline & \multirow{2}{*}{ Human excreta disposal system } & Improved, latrine & 100 & 26.2 \\
\hline & & No latrine/bush/field & 282 & 73.8 \\
\hline \multirow{5}{*}{ Household's housing condition ( $\mathrm{n}=382$ ) } & \multirow{2}{*}{ Roof of the house } & Thatched & 68 & 17.8 \\
\hline & & Corrugated iron sheet & 312 & 81.7 \\
\hline & \multirow{3}{*}{ Floor of the house } & Earth & 23 & 6.0 \\
\hline & & Wood & 33 & 8.6 \\
\hline & & Concrete & 261 & 68.3 \\
\hline
\end{tabular}

\section{Prevalence and Predictors of Protein Energy Malnutrition in Wondogenet District Sidama Zone, Southern Ethiopia April 2017}

All types of protein energy malnutrition were a public health challenges in the study area. Stunting is the most leading prevalent case and accounting for $45.5 \%$ of the cases followed by underweight and severe wasting having a share of $38.7 \%$ and $15.7 \%$ respectively (Figure 3 ).

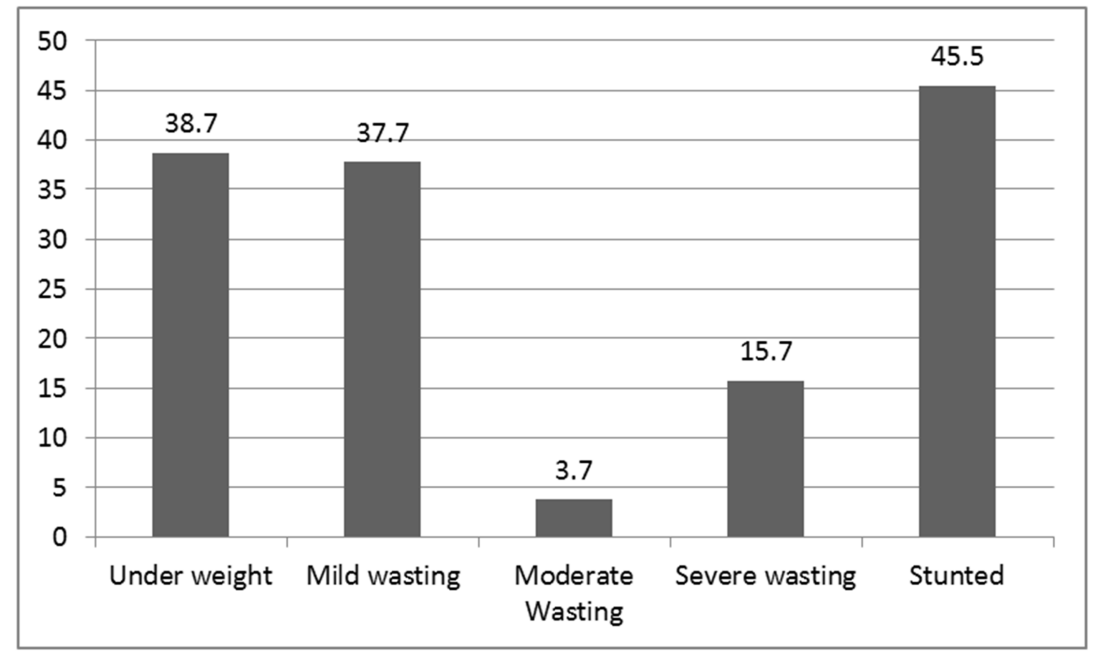

Figure 3. Prevalence of Malnutrition in Wondogenet district, Sidama zone Southern Ethiopia April 2017.

We assessed the association of dependent and independent variable using bivariate and multivariate logistic regression. Accordingly, we transfer those variables showing p-value of $<0.5$ in biviriate logistic regression model into multiple logistic regression model to rule out confounders. As a result, in multivariate analysis age of the children, Weight of children at birth and food distribution experience in the households were independent predictors of protein energy malnutrition in children aged 6-59 months. Accordingly, children with the age of 2 years and below were more likely to become malnourished $[\mathrm{AOR}=0.278 \mathrm{CI} 95 \% 0.115-0.671][17,18]$ as compared to their counter parts. Similarly, children weighing $2.5 \mathrm{KGs}$ and above at birth were less likely to become malnourished $[\mathrm{AOR}=0.213 \mathrm{CI} 95 \% 0.063-0.720]$ than their counterparts, weighing higher than $2.5 \mathrm{KGs}$ at birth. Moreover, children having given priority in food distribution were less likely to become malnourished $[\mathrm{AOR}=0.413 \mathrm{CI} 95 \% 0.176$ 0.973 ] as compared to their country parts (Table 5). 
Table 5. Independent Predictors of Malnutrition of Children Aged 6-59 Months in Wondogenet District, Sidama Zone Southern Ethiopia April 2017.

\begin{tabular}{|c|c|c|c|c|c|}
\hline \multirow[b]{2}{*}{ Variables } & & \multicolumn{2}{|l|}{ Nutritional status } & \multirow[b]{2}{*}{ AOR (95\%CI) } & \multirow[b]{2}{*}{ P-value } \\
\hline & & $\begin{array}{l}\text { \# and percent of normal } \\
\text { children }\end{array}$ & $\begin{array}{l}\text { \# and percent of malnourished } \\
\text { children }\end{array}$ & & \\
\hline \multirow{2}{*}{ Children age } & $<2$ years & $16(13.2 \%)$ & $105(86.8 \%)$ & $0.578(0.115-0.671)$ & 0.004 \\
\hline & $>2$ years & $8(4.1 \%)$ & 189 (95.9\%) & 1 & \\
\hline \multirow{2}{*}{ Weight at birth $(\mathrm{kg})$} & $<2.5$ & $4(25 \%)$ & $12(75 \%)$ & $0.213(0.063-0.720)$ & 0.013 \\
\hline & $>2.5$ & $20(6.6 \%)$ & $282(93.4 \%)$ & 1 & \\
\hline \multirow{2}{*}{$\begin{array}{l}\text { Food distribution in } \\
\text { Household }\end{array}$} & No priority to child & $10(13 \%)$ & $67(87 \%)$ & $0.413(0.176-0.973)$ & 0.043 \\
\hline & Priority to child & $14(5.8 \%)$ & $227(94.2 \%)$ & 1 & \\
\hline
\end{tabular}

\section{Discussion}

Failure to provide sufficient nutrients during rapid rates of growth results in malnutrition and it is complex in its etiology and cumulative in its manifestations. Communicable diseases and protein energy malnutrition represent the major health problems and children are the more vulnerable group to these problems in Ethiopia like other developing countries [2]. Moreover, malnutrition is considered as a public health challenge and prevalent in many regions of Ethiopia. According to EDHS 2014 report, the national prevalence of underweight and stunting were $9 \%$ and $6.8 \%$ respectively, and likewise the figure exceeded by three folds in southern region, where the prevalence was $25 \%$ underweight and $26.3 \%$ stunting on children aged below five years [19].

In this study, the prevalence of stunting and underweight was $45.5 \%$ and $38.7 \%$ respectively and it was yet very much higher than that of national and regional figure of EDHS 2014. In addition, the prevalence of underweight in the study is higher than reports from other studies in Bure town, northern Ethiopia and in Kenya, where the prevalence was $14.3 \%$ [20] and $26.5 \%$ [21] respectively. The possible explanation could be variation in study methods and sample size, and socioeconomic and cultural differences among the countries.

Furthermore, magnitude of stunting in this study was consistent with studies conducted in different parts of Ethiopia; wollo and Bule Hora districts, where the stunting was $44.5 \%$ and $47.6 \%$ respectively $[22,23]$ but it was slightly lower than the studies reported in India and Khartoum where there was $49.36 \%$ [24] and 51\% [25] prevalence respectively. However, it was higher than the survey conducted in sub-Saharan Africa and south Asia [26] as UNICEF reported in the year 2013 where the prevalence was $40 \%$ and $39 \%$ respectively. In addition, the prevalence of stunting in this study is much higher than the report from Bure town, where it was $35.5 \%$ [20]. The possible explanation could be variation in mother's educational status and socio economic differences among the countries and urban and rural dwellers as well.

In this study, the prevalence of severe wasting was $15.7 \%$ which is higher than the survey report from Nigeria in 2014, which was 9.5\% [27]. The possible explanation could be variation in sample size and study period. It might be also due to differences in socioeconomic status and feeding habit between countries. In contrast to this, it is better than the finding in India where the severe wasting was $28.5 \%$ [24].

This study showed that weight at birth, child age and food distribution in the family were independent predictors of protein energy malnutrition. Other comparable report in butajira, south west Ethiopia showed that male sex, weight at birth, poor maternal nutritional status, and rural residence were factors affecting infant's nutritional status [28]. In addition, other study conducted in Somalia region, Eastern Ethiopia, age and sex of the child, mother's education and household's monthly income were factors associated with malnutrition [29]. According to reported from North wollo, Amhara regional state, age and sex of the children were found to be factors associated with protein energy malnutrition [22].

In the study, age of the child was found to be one of independent predictors of protein energy malnutrition. The finding is in line with studies conducted in Tigray region, North Ethiopia and Nigeria [13,30], and this explains that as the age of child increases, the risk of being undernourished increases. One possible clarification could be because of the late introduction of supplementary food with low nutritional quality [31]. The other reason might be the large portions of caretakers neglect to fulfill optimal food requirements of their children as the child's age increases [32].

Low birth weight is also one of the predictors of protein energy malnutrition in this study. It was consistent with reports of other studies in butajira, south west Ethiopia [28], china [18] and Bangladesh [33]. According to the studies, there was a strong association between low birth weight and protein energy malnutrition. It was also sorted out that there is increased vulnerability of children with low birth weight to infections, such as diarrheal and lower respiratory tract infections and other increased risk of complications such as sleep Apnea, anemia and poor appetite as compared to children with normal birth weight. Greater morbidity among children with low birth weight resulted in poor physical growth and development that is perceived as protein energy malnutrition [18, 28, 33].

This study revealed that there is association between food distributions in the family with nutritional status of the children. In the study, children in a family with priority to the child on food distribution were less likely to be malnourished than children in a family with priority was set to heads of households or equal distribution for all family members. The finding is consistent with Ethiopian demographic and health 
survey report in 2014 [19], where the food distributions within the family member is severely affecting children aged below five years and their mothers. Possible explanation for this could be Children are in a fast growth state and they need more balanced diets for body building more than older family members.

As a result, Ethiopian Ministry of Health considered the policy direction recommending for increased efforts to enhance good nutritional practices through health education and treatment for extremely malnourished children, and provision of micronutrients to the most vulnerable group of the population such as pregnant women and children aged below five years [34]. In addition, the Health Extension Program has included nutrition as part of the program packages [35].

\section{Conclusions and Recommendations}

In Conclusion, the study revealed that prevalence of malnutrition in children under five years of age found to be a major problem in the study community. Age of children, weight at birth of children and food distributions in the households with risks of house hold food insecurity found to be important independent predictors of malnutrition.

Thus, it is recommended that priority on provision of balanced diet needs to be considered to children aged 6-59 months. The parents have to increase the frequency on daily feeding practices and timely introduction of supplementary food with optimal nutritional quality. The caretakers must be provided with important home based training in order to avoid negligence, and to fulfill optimal food requirements of children as their age increases. The health institution should improve the proper identification of weigh at birth, and early diagnosis and timely management of neonatal and childhood illnesses related to malnutrition. Furthermore, the healthcare facilities should strive to equip the health facilities with standard resources. All responsible bodies and respective sectors like Health, Water, Agriculture, Environmental Sustainability and Trade and Industry should work hard to ensure food security in the households and to improve general socioeconomic development of the country.

\section{Acknowledgements}

We would like to thank College of public health and medical sciences of Hawassa University for funding this research. Our gratitude goes to southern regional health bureau, Wondogenet district health office, all data collectors, supervisors, data manager and study participants for their contribution and cooperation in the study process.

\section{Authors' Contributions}

Herein mentioned authors, Rodamo KM, Fiche YA, Geleto FB, Abebe RF' Dangiso DD, have conceived the study and contributed in study design, analysis and writing the paper.

\section{References}

[1] FAO I, UNICEF, WFP, WHO,. The State of Food Security and Nutrition in the World 2017. Building resilience for peace and food security. Rome, FAO: 2017.

[2] UNICEF. One is too many. Ending child deaths from pneumonia and diarrhoea One is too many Ending child deaths from pneumonia and diarrhoea. New York, NY 10017, USA: 2016.

[3] UNICEF. Under nutrition contributes to half of all deaths in children under 5 and is widespread in Asia and Africa.. Available from http:// www.UNICEF.org/ UNICEF statistics.html. Report. 2015 Feb 15.

[4] Fatima ea. Socio - economic and environmental risk factors of protein energy malnutrition among children under five years of age in Omdurman pediatric hospital.. thesis. 2013.

[5] WHO. World Health Organization, Geneva, Switzeraland, Report. 2011.

[6] Ethiopia FMoH. Severe Acute Malnutrition guideline final Manual. March 2007.

[7] Nelson Text Book of Pediatrics 19th edition.

[8] R. E. Black, C. G. Victora, al. SPWe. Maternal and child undernutrition and overweight in low-income and middle income countries. The Lancet. 2013; vol. 382 (9890):pp. 427-51.

[9] Save the children. "A life free fromhunger: Tackling Child Malnutrition: report by Save the children International," Geneva.. report. Feb, 2012.

[10] World Health Organization. Essential Nutrition Actions: Improving Maternal, Newborn, Infant and Young Child Health and Nutrition, WHO Document Publications Services, Geneva, Switzerland,. Report. 2013.

[11] D. Headey. "An analysis of trends and determinants of child under nutrition in Ethiopia, 2001-2011," International Food Policy Research Institute Working Paper 70, EDRI, Washington Dc, USA.

[12] Ethiopia National Nutrition Programme Implementing Sectors Declaration, "Government of the Federal Democratic Republic of Ethiopia (2013-2015)”. (2013-2015).

[13] Save the children. National Nutrition Strategy: Review and Analysis of progress and Gaps, One year on, save the children UK, London, UK. report. 2009.

[14] CSA, MoH. Ethiopia Mini Demographic and Health Survey 2014. Addis Ababa, Ethiopia: 2014.

[15] Endris N, Asefa H, Dube L. Prevalence of Malnutrition and Associated Factors among Children in Rural Ethiopia. Hindawi BioMed Research International. 2017.

[16] Central Statistical Agency, International I. Ethiopia Demographic and Health Survey 2011. Addis Ababa, Ethiopia and Calverton, Maryland, USA: Central Statistical Agency and ICF International.. Report. March 2012; 155-162.

[17] M. Ozor, o. iyamu a, U. Osifo. Prevalence of under nutrition among under five children in. Ekpoma, Edo-Nigeria international journal of community research. 2014 vol. 3, :pp. 34-8. 
[18] J. Zhang, J. Shi, al JHHe. Under nutrition status of children under 5 years in Chinese rural areas- data from the national rural children growth standard survey Asia pacific journal of clinical nutrition. 2011; volt. 20 (no. 4 ):pp. 584-92.

[19] Central Statistical Agency, International aI. Ethiopia Demographic and Health Survey 2014. Addis Ababa, Ethiopia and Calverton, Maryland, USA: Central Statistical Agency and ICF International.. March 2014; 155-162.

[20] Bureau ARH. The overall prevalence of undernutrition among children below five years of age in bure town, west gojjam zone, Amhara national regional state, northwest Ethiopia. From research conducted, in. 2016

[21] F. N, Kariuki J, Monari. M, al MKe. Prevalence and risk factors of malnutrition. Journal of the National Institute of public health. 2002.; vol. 51, no. 1,

[22] FMOH. Risk factors for child under-nutrition with a human rights edge in rural village of North Wollo, Ethiopia,. East Africa Medical journal,. 2005,; vol. 82, no. 12, :pp. 625-30.

[23] M. Asfaw, M. Wondaferash, M. Tata a, L. Dube. "Prevalence of under nutrition and associated factors among children aged between 6-59 months on bule hora district, south Ethiopia, BMC public health. 2015.; vol. 15 article. 41,

[24] H. T, and P, S. A. Singru. Various anthropometric methods of assessment of nutritional status in under five children. Indian medical Gazette,. 2012; vol. 9 no. 1, :pp. 349-51.

[25] A. Mahgoub, Alsheik A. The impact of feeding practices on prevalence of under nutrition among 6-59 months aged children in Khartoum. Sudanese journal of public health. 2010; vol. 5 , no. 3 pp. $152-7$.

[26] UNICEF. Improving Child Nutrition: The Achievable Imperative for Global progress, United Nations Children's Fund Report. 2013.

[27] M. Ozor, o. iyamu a, U. Osifo. Prevalence of under nutrition among under five children in. Ekpoma, Edo-Nigeria international journal of community research. 2014 vol. 3, :pp. 34-8.

[28] G. Medhin, C. Hanlon, al MDe. Prevalence and predictors of under nutrition among infants aged six and twelve months in Butajira, Ethiopia: the p-MaMiE Birth cohort. BMC public Health,. 2010; volt 10.

[29] S. Demissie. Magnitude and factors associated with malnutrition in children 6-59 months of age in pastoral community of Dollo Ado District, Somali Region, Ethiopia,. "Science journal of public Health,. 2013; volt. 1, no4, :p. 175.

[30] I. O. Sebanjo, O. O. Adeodu a, E. A. Adejuyigbe. Influence of socio-economic factors on malnutritional status of children in a rural community of Osun State, Nigeria. 2009.

[31] AS. Dasgupta, R. Parthasarathi, v. Ram Prabhakar, R. Biswas a, A. Geethanjali. Assessment of under nutrition with composite index of anthropometric failure (CIAF) among under five children in rural area of west Bengal Indian journal of community health,. 2014; volt. 26, (no. 2):pp. 132-8.

[32] E. R, and AK, Rasa MA. Determinants of malnutrition in Indian children: new evidence from IDHS through CIAF. International journal of Methodology. 2016; volt. 50 (no. 1):pp. 299-316.

[33] Association of low birth weight with malnutrition in children under five years in Bangladesh, published online,. 2016.

[34] Sebanjo IO. An assessment of the causes of malnutrition in Ethiopia: A contribution to the formulation of a National Nutrition Strategy for Ethiopia. International Food Policy Research Institute Washington, DC, USA. November 2005.

[35] Nejmudin Kedir Bilal, Christopher H. Herbst, Feng Zhao, Agnes Soucat, Lemiere aC. Health Extension Workers in Ethiopia: Improved Access and Coverage for the Rural Poor 2005. 